\title{
Attention Deficit Hyperactivity Disorder Associated with Lissencephaly Type I
}

\author{
Lizensefali Tip 1'in Eşlik Ettiği Dikkat Eksikliği ve Hiperaktivite Bozukluğu
}

\author{
Tülin Fidan', Dilcan Kotan², İsmet Kırpınar ${ }^{3}$ \\ ${ }^{1}$ Atatürk Üniversitesi Tıp Fakültesi Çocuk Psikiyatrisi Anabilim Dalı, Erzurum \\ ${ }^{2}$ Sakarya Üniversitesi Tıp Fakültesi Nöroloji Anabilim Dalı, Sakarya \\ ${ }^{3}$ Atatürk Üniversitesi Tıp Fakültesi Psikiyatri Anabilim Dalı, Erzurum
}

\begin{abstract}
Attention deficit/hyperactivity disorder (ADHD) is is characterized with inattention, distractibility, restless, hyperactivity, impulsiveness and other deficits of executive function. In ADHD there is evidence of structural and functional differences in the brain. It is known that pschomotor retardation was seen clinically in migration anomalia. We are presenting a girl having migration anomalia and severe symptoms of $A D H D$.
\end{abstract}

Keywords: Attention deficit/hyperactivity disorder, lissencephaly, MRI

Aplication: 25.03.2011 Accepted: 31.05.2011
Özet

Dikkat Eksikliği Hiperaktivite Bozukluğu (DEHB) dikkatsizlik, dikkat dağınıklığı, yerinde duramama,aşırı hareketlilik, dürtüsellik ile karakterizedir. DEHB'de beyinde yapısal ve fonksiyonel değişikliklerin olduğuna dair kanıtlar vardır. Migrasyon anomalisinde psikomotor retardasyonun var olduğu bilinmektedir. Bu yayında, migrasyon anomalisi ve ağır derecede DEHB bulguları olan bir kız çocuğu sunuldu.

Anahtar Kelimeler: Dikkat Eksikliği Hiperaktivite Bozukluğu, lizensefali, MRI

Başvuru Tarihi: 25.03.2011 Kabul Tarihi: 31.05.2011

\section{Introduction}

Attention deficit/hyperactivity disorder (ADHD) is one of the most common childhood onset psychiatric disorders, affecting $5-12 \%$ of children worldwide. It is characterized with inattention, distractibility, restless, hyperactivity, impulsiveness and other deficits of executive function. The etiology of ADHD is complex and most likely includes genetic, neurodevelopmental factors and neuroimaging findings. ${ }^{1}$ Prefrontal, parietal, and temporal association cortices, and their projections to the striatum, make distinct contributions to the core ability to focus attention. The prefrontal cortex allow us to inhibit inappropriate behaviors and to attenuate the processing of irrelevant stimuli. It is postulated that fetal insults, particularly during the second trimester during the height of neural development may cause subtle functional abnormalities to the frontal cortex and other brain structures. In ADHD there is evidence of structural and functional differences in the brain such as smaller right sided prefrontal regions in boys and smaller left and total caudate volumes in girls. ${ }^{2}$

Normal development of the cerebral cortex requires long-range migration of cortical neurons from proliferating regions deep in the brain. The term lissencephaly covers a group of rare malformations sharing the common feature of anomalies in the appearance of brain 
convolutions (characterized by simplification or absence of folding) associated with abnormal organization of the cortical layers as a result of neuronal migration defects during embryogenesis. Lissencephaly ("smooth brain," from "lissos," meaning smooth, and "encephalos," meaning brain) is a severe developmental disorder. It manifests along with various syndromes and there are various types. ${ }^{3}$

Most types result from incomplete neuronal migration to the cortex during the third and fourth months of gestation. ${ }^{4}$ It is characterized by a smooth cerebral surface, incomplete neuronal migration, and secondary abnormalities such as mental retardation, seizures, and minor facial dysmorphisms. ${ }^{5}$ Lissencephaly has specific radiographic and clinical findings. The primary findings consist of: 1. a cerebral surface that is agyric or agyric with pachygyric areas, 2 . a cerebral contour that is oval or "hourglass" due to lack of or incomplete opercularization of the brain, and 3. an abnormal gray-white-matter distribution in the cerebral hemispheres. The primary findings are necessary to make the diagnosis, which can be made with MR. ${ }^{6}$

Multiple forms of lissencephaly have been described and their current classification is based on the associated malformations and underlying etiology. Two large groups can be distinguished: classical lissencephaly (and its variants) and cobblestone lissencephaly. ${ }^{3}$

In classical lissencephaly (or type I), the cortex appears thickened, with four more or less disorganised layers rather than six normal layers. The incidence of all forms of type I lissencephaly is around 1 in 100,000 births. Cobblestone lissencephaly (formally referred to as type II) is characterized by global disorganization of cerebral organogenesis with an uneven cortical surface (with a pebbled or cobblestone appearance) that is characterized by total disorganization of the cortex and the absence of any distinguishable layers. Management is symptomatic only. The epilepsy is often resistant to treatment. The encephalopathy associated with lissencephaly is often very severe, and affected children are completely dependent on the care taker. ${ }^{3}$
To the best of our knowledge, Attention deficit/hyperactivity disorder (ADHD) have not been reported with lissencephaly type I. We are presenting a girl having severe ADHD symptoms and treated with methlyphenidate that has a side effect of seizure.

\section{Case Report}

A 7-year-old female child was admitted to the child psychiatry outpatient clinic, with the complaints of inattention, hyperactivity, difficulty in learning, difficulty in peer relationships, bad temper, and self mutilation. The parents was divorced 2 years ago and the patient was living with her mother. In her developmental history, there was a distinguished delay in her talking and comprehension skills. When she was 6 months old, her mother noticed that she was more hyperactive than her peers, The child was in a totally restlesss state as observed by the mother. She was not able to play with her peers but only with children older than her.

In the psychiatric examination, short attention time and distractibility were noted along with marked hyperactivity. In the psychometric examination, Welchler Intelligence Test for children (WISCR) revealed mild mental retardation (IQ: 60). In her neurologic examination microcephaly, convulsions and spelling was not found. Routine laboratory and EEG findings were normal. On the $\mathrm{MRI}$, the gyri of bilateral frontal and temporal lobes were thick and wide, bilateral fronto temporapariatel incomplete lissencephaly (agria and pachygyria ) was determined and congenital anomalia was not found (Figure 1: Agyria and Pachygyria T2 weighed coronal section on MRI, Figure 2: Agyria and Pachygyria T1 weighed axial section on MRI).

According to DSM-IV TR, the patient was diagnosed with attention deficit hyperactivity disorder-combined type with migration anomaly. Methylphenidate $(10 \mathrm{mgr} /$ day) was prescribed and her ADHD symptoms improved dramatically. No epileptic seizures were observed after treatment with methylphenidate (psychostimulan medication) According to Clinical Global Impression Scale (CGI), the severity of illness score before the treat 
Figure 1: Agyria and Pachygyria T2 weighed coronal section on MRI

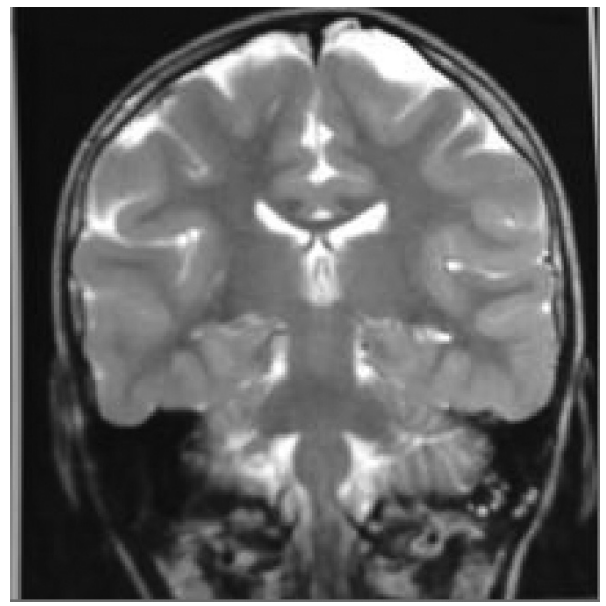

Figure 2: Agyria and pachygyria T1 weighed axial section on $\mathrm{MRI}$

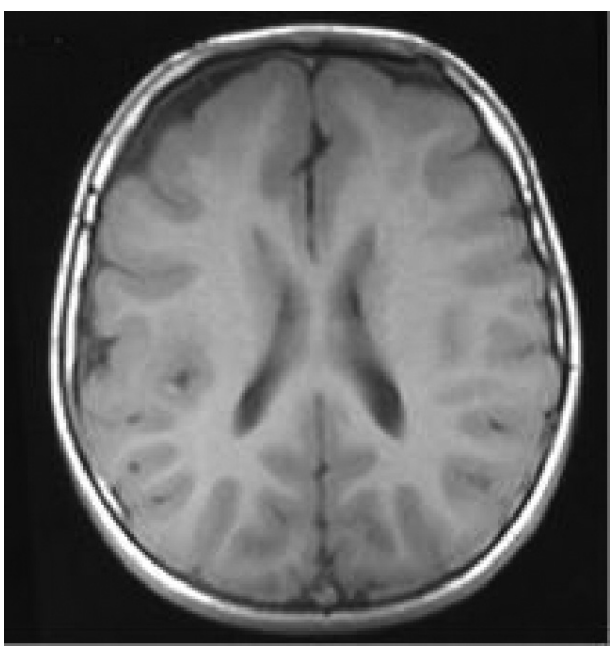

ment was 6 and after the treatment, 2, while the improvement score was 2. Efficacy Index was 0. According to Children's Global Assessment Scale (C-GAS), functioning score before the treatment was 35 and after the treatment, 75.

In a 1-year follow-up, the patient was attending to a rehabilitation and training school for children with intellectual disability, and also she was more concordant with her peers.

\section{Discussion}

Children with lissencephaly have feeding and swallowing problems, muscle tone anomalies (early hypotonia and subsequently limb hypertonia), seizures (in particular, infantile spasms) and severe psychomotor retardation. ${ }^{3}$ Nevertheless, in our patient, rather than psychomotor retardation, hyperactivity was prevalent, and the patient was diagnosed with Attention Deficit/Hyperactivity Disorder (ADHD).

The most consistent structural brain imaging findings in children with ADHD have been significantly smaller volumes in the dorsolateral prefrontal cortex, caudate, pallidum, corpus callosum, and cerebellum. The patients with ADHD had significantly smaller brain volumes on the initial scan in all the regions (total cerebrum; cerebellum; gray and white matter for the four major lobes: frontal, temporal, parietal and occipital). Unmedicated children with ADHD had significantly smaller total cerebral volumes and significantly smaller total white matter. The volumetric abnormalities persisted with age in total and regional cerebral measures and in the cerebellum, except for the caudate nucleus volumes that were initially abnormal for patients with ADHD but lost the diagnostic difference from controls during adolescence. Developmental trajectories for all the structures except the caudate remained roughly parallel for patients and controls during childhood and adolescence and are unrelated to stimulant treatment. ${ }^{7}$

In ADHD, there were anatomical and functional disturbances but to the best of our knowledge, this is the first case in which there was migration anomaly as Lissencephaly type I associated with ADHD. Structures that have been implicated in the pathophysiology of ADHD include the Cerebral gray (GM) and white (WM) matter abnormalities examined in a group of ADHD children using a voxel-based morphometry protocol. ADHD brains on an average showed a global volume decrease of $5.4 \%$ as compared to controls. Additionally, there were regionally specific effects in the left fronto-parietal areas (left motor, premotor and somatosensory cortex), left cingulate cortex (anterior /middle/ posterior cingula- 
te), parietal lobe (precuneus bilaterally), temporal cortices (right middle temporal gyrus, left parahippocampal gyrus), and the cerebellum (bilateral posterior). ${ }^{8}$

Seizures and delayed development are often the presenting symptoms in patients with agyria-pachygyria. Although all of these patients were retarded in either motor or intellectual functions, the clinical features and neurodevelopmental dysfunction were diverse and suggest dependence on the extent, distribution, and detailed structure of agyria-pachygyria. ${ }^{9}$ The severity of psychomotor retardation may not completely correspond to the degree of image abnormalities and may partially be related to the age at seizure onset. Patients with agyria and those who had earlier onset of seizures had the worse outcome. ${ }^{10}$ Our patient had no seizure history; thus, the-

\section{References}

1. Spetie L, Arnold LE: Attention-Deficit/Hyperactivity Disorder; in: Andres M, Volkmar FR (eds): Lewis's Child and Adolescent Psychiatry: A Comprehensive Textbook 4th Edition. USA Lippincott Williams \& Wilkins 2007, pp 431-454.

2. D. Stubbe, Attention-Deficit/Hyperactivity Disorder In: Child and Adolescent Psychiatry, K Cheng, K.M.Myers, Editors, Lippincott Williams \& Wilkins, USA (2005).

3. Verloes A, Elmaleh M, Gonzales M, Laquerrière A, Gressens $P$ : Genetic and clinical aspects of lissencephaly. Rev Neurol 2007;163(5):533-547.

4. Dobyns WB, Truwit CL: Lissencephaly and other malformations of cortical development: 1995 update, Neuropediatrics 1995;26(3):132-147.

5. Pavone L, Rizzo R, Dobyns WB:Clinical manifestations and evaluation of isolated lissencephaly, Childs Nerv Syst. 1993;9(7):387-390. re was no psychomotor retardation.

In neuronal migration disorders, seizures are usually resistant to treatment. ${ }^{3}$ It is known that stimulants may lower the convulsive threshold. In this case we prescribed methylphenidate for severe ADHD symptoms and the patient remained seizure free.

In ADHD, there were anatomical and functional disturbances, this case is interesting that having migration anomalia and diagnosed as ADHD. The pharmacological agents that were using in the treatment of ADHD might have cause seizures as a side effect.

In cases having migration anomalia, ADHD symptoms could be treated with methylphenidate.

6. Byrd SE, Bohan TP, Osborn RE, Naidich TP: The CT and MR evaluation of lissencephaly, AJNR Am J Neuroradiol. 1988;9(5):923-927.

7. Castellanos FX, Lee PP, Sharp W, Jeffries NO, Greenstein DK, Clasen LS et al.: Developmental trajectories of brain volume abnormalities in children and adolescents with attention deficit hyperactivity disorder, JAMA 2002;288:1740-1748.

8. Carmona S, Vilarroya $O$, Bielsa $A$ : Global and regional gray matter reductions in ADHD: A voxel-based morphometric study, Neurosci Lett. 2005;389(2):88-93.

9. Aicardi J: The agyria-pachygyria complex: A spectrum of cortical malformations, Brain Dev 1991;13:1-8.

10. Liang JS, Lee WT, Young C, Peng SS, Shen YZ: Agyriapachygyria: clinical, neuroimaging, and neurophysiologic correlations, Pediatr Neurol. 2002;27(3) :171-176. 